\title{
Kultura popularna jako semiologia codzienności
}

DOI: http://dx.doi.org/10.12775/RF.2014.004

Kultura popularna to wciąż zadziwiające signum ponowoczesności. Jej społeczne rozpanoszenie się, wtargnięcie do wszelkich możliwych obszarów zbiorowej egzystencji, zdobycie i zdominowanie świadomości powszechnej - oto trwałe sukcesy zjawiska kultury popularnej. Zaanektowanie ludzkiego sposobu myślenia przez obrazy, formy ustawicznie powielane, znaki nieustannie kopiowane (albo - mówiąc dokładniej siebie kopiujące), oto przykra diagnoza płynnej nowoczesności, w której poddajemy się ułudzie towarów, nęceni szybkim zdobyciem prestiżu społecznego (pogłębiającym jedynie permanentną alienację) albo partycypacją w proponowanym modelu życia, generowanym przez machinę medialną ${ }^{1}$.

Ułuda, z jaką spotykamy się w alternatywnych stylach życia, pociąga masy. Ludzie pragną życia wygodnego i nieograniczonego, w pełni dostępnego za sprawą konsumpcji. Chcą nabywać (kupować) nową tożsamość grupowa, windującą status społeczny, przynoszącą szybkie i długotrwałe (przez kultywowanie gromadzenia dóbr) zadowolenie. Celem masowości jest ścisłe integrowanie społeczeństwa wedle jednolitych wzorców, zglajchszaltowanych typów bycia. Jednostka masowa, powstała na skutek Wielkiej Rewolucji Francuskiej (co spowodowało demokratyzację życia oraz rozrost aglomeracji) i gwałtownego rozwoju techniki, jednak jej ugruntowanie (przepowiadające reguły nowoczesności) odnajdujemy $\mathrm{w}$ mieszczaństwie dziewiętnastowiecznym, zna-

1 Na temat demaskacji i opisu ukrytych przymusów oraz postaw zmedializowanej hoi polloi zob. P. Bourdieu, O telewizji. Panowanie dziennikarstwa, przeł. K. Sztandar-Sztanderska, A. Ziółkowska, Wydawnictwo Naukowe PWN, Warszawa 2011. 
mionującym wejście człowieka pospolitego na arenę dziejów. Wszystkie przedsięwzięcia architektoniczne (jak dworce, hale wystawowe, domy towarowe), odpowiadały potrzebom zbiorowym i generowały masowe gusta.

Uczestnik aktów, rytuałów i celebracji codziennego życia jest bytem spektralnym, odnajdującym w spojrzeniu Innego własną tożsamość. To, co jednostkowe, jest zarazem najbardziej ogólne. Mogę narodzić się jako właściciel własnego ciała, gestów i aktów, tylko zakotwiczając się w pożądaniu - permanentnej obecności tego, co nieobecne. Przestrzeń publiczna, pozwalająca przez zapośredniczenie bezpośredniości narodzić się temu, co subiektywne, jest najważniejszym wynalazkiem nowoczesności. Wkroczenie $\mathrm{w}$ zbiorowość, $\mathrm{w}$ wyniku otwarcia miejsca na spotkanie z Innym, umożliwia sytuację, w której odnajduję swoje Ja przez tego Innego wypowiedziane. W zewnętrzności napotykania odnajduję swoje wnętrze - wyrwę w porządku publicznym, która zarazem ustanawia ową przestrzeń i mnie jako kogoś, kto do niej wkracza. Tak powstaje kategoria flâneura - kogoś, kto przechadza się po ulicy (niczym po własnym mieszkaniu), odnajdując prawdę swojego oblicza w odbijających go wystawach sklepowych.

Flâneur stoi jeszcze na progu zarówno wielkiego miasta, jak i klasy mieszczańskiej. Nie pokonało go na razie żadne z tych dwojga. Nie zadomowił się w żadnym $\mathrm{z}$ nich. Schronienia szuka $\mathrm{w}$ tłumie. Pierwsze przyczynki do fizjonomiki tłumu, znajdujemy u Engelsa i Poego. Tłum jest woalem, poprzez który znajome miasto majaczy flâneurowi na kształt fantasmagorii. W niej raz jest ono pejzażem, raz izbą. Oba potem urzeczywistniają się $\mathrm{w}$ domu towarowym, który samą flânerie wykorzystuje do zwiększenia sprzedaży. Dom towarowy jest ostatnim rewirem przechadzek flâneura ${ }^{2}$.

Przechodzień nie jest, ściśle rzecz ujmując, kimś, kto wkracza w przestrzeń miejską, ale kimś, kto jest przez ową labiryntowość pasaży i ulic zrodzony. Spacerowicz odnajduje siebie w miejscach, w których już był. Rytm jego kroków jest jednocześnie rytmem odkrywania obszarów miejskich. Pozwala mu uczestniczyć w orgii doznań wizualnych, zatapiając go w jednolitej masie konsumentów.

Przyjęcie takiej perspektywy jest jednakże niesprawiedliwe wobec zasobu możliwości, skrywanych przez popkulturę. Należy wyraźnie podkreślić terminologiczne nadużycie przy wymiennym zastosowaniu pojęć kultura masowa i popularna. Chociaż obydwie stanowią kulturę ludu, to ich zakres znaczeniowy jest nieprzystawalny. Popkultura i kultura masowa są całkowicie odmienne. Nie pozostają ze sobą w żadnym związku (mimo że takie mylne interpretacje się zdarzają świadcząc

2 W. Benjamin, Pasaże, przeł. I. Kania, Wydawnictwo Literackie, Kraków 2005, s. 41 . 
o pojęciowym bałaganie i dezynwolturze znaczeń). Co więcej, pomimo występowania społeczeństwa masowego, kultura masowa zwyczajnie nie istnieje!

Termin kultura masowa stosują ci, którzy sądza, że towary kulturowe, wytwarzane i rozpowszechniane przez odrębne gałęzie przemysłu można ludziom narzucić w sposób, który wygładza różnice społeczne i skutkuje powstaniem ujednoliconej kultury, przeznaczonej dla biernego i wyobcowanego odbiorcy masowego. Gdyby taki proces rzeczywiście istniał, a nie istnieje, byłby on antykulturowy i antypopularny. Stanowiłby antytezę zarówno przyjemności i kultury, rozumianej jako produkcja i rozpowszechnianie znaczeń, jak i tego, co popularne, tj. upartego, przeciwstawnego, sprzeciwiającego się układu sił. Kultura masowa nie istnieje. To, z czym mamy do czynienia, to tylko pesymistyczne, podszyte paniką teorie kultury masowej, które w najlepszym wypadku, rzucają nieco światła na przemysłowe i ideologiczne imperatywy, obowiązujące w bloku władzy. Żadna z tych teorii natomiast w najmniejszym stopniu nie wyjaśnia zasad działania procesów kulturowych, które świadczą o tym, że ludzie radzą sobie z rozmaitymi formami przymusu i albo je odrzucaja, albo zmieniają w kulturę popularnąa ${ }^{3}$.

Popkultura jest najradykalniejszym przekroczeniem oświeceniowego ratio; zerwaniem ze zwyrodniałym mitem Aufklärung. Zanim jednak to nastąpiło, została ona poddana logice fabrycznej produkcji rozrywki. Organizowano ją zgodnie z regułami przemysłowymi. Jej zadaniem było - za sprawą niesionych treści - zhomogenizowanie mas. Rolą kultury przestało być kształtowanie ludzkiego ducha, emancypowanie osobowości. Kultura stała się elementem gry rynkowej, mającej przynosić zyski. Kapitalistyczna zasada reprodukcji podobieństw nadała kulturze status przemysłu kulturalnego, przemieniając jego odbiorców w konsumentów.

Konsument w swym czasie wolnym ma się kierować jednością produkcji. To, czego kantowski schematyzm oczekiwał jeszcze od podmiotów, mianowicie apriorycznego odnoszenia zmysłowej różnorodności do fundamentalnych pojęć - zostaje podmiotowi odebrane przez przemysł. Schematyzm to główna usługa, jaką przemysł świadczy na rzecz klientów. [...] Przemysł kulturalny rozwinął się pod znakiem dominacji efektu, konkretnego rozwiązania, technicznego szczegółu nad dziełem, które kiedyś było nośnikiem idei i wraz z nią uległo likwidacji. Szczegół, emancypując się, zrobił się krnąbrny i od romantyzmu po ekspresjonizm buntował się przeciwko organizacji. Harmonijne działanie szczegółów zatarło w muzyce świadomość całościowej formy, partykularny kolor zatarł w malarstwie kompozycję, psychologiczna dobitność zatarła ar-

3 J. Fiske, Zrozumieć kulturę popularna, przeł. K. Sawicka, Wyd. UJ, Kraków 2010, s. $183-184$. 
chitekturę powieści. Przemysł kulturalny przez swoją totalność kładzie temu kres. Ponieważ nie zna niczego prócz efektów, łamie ich nieposłuszeństwo i podporządkowuje je formułce, zastępującej dzieło. Niszczy na równi całość i część ${ }^{4}$.

Współczesna spopularyzowana kultura przyjmuje zarówno formę dominacji, jak i wytwarza środki oporu wobec niej. Problem nie polega już na rozgraniczeniu społeczno-ekonomicznej bazy i kulturowej nadbudowy, ani tym bardziej na chęci zapanowania nad bazą przez narzucane wzorce, lecz na kompletnym zlaniu się jednej z drugą.

Kultura jest tak wszechobecna, że wylewa się poza nadbudowę, by przeniknąć do bazy, a następnie objąć nad nią kontrolę. [...] Kultura - czy to w odniesieniu do praktyk dominacji, czy oporu - nie działa już przede wszystkim jako nadbudowa. Nie działa już jako hegemoniczna ideologia, zestaw symboli i reprezentacji. W rodzącej się na naszych oczach nowej erze globalnego przemysłu kulturowego kultura - dominująca zarówno nad gospodarka, jak i nad życiem codziennym - przestaje być procesem reprezentacji, ulegając urzeczowieniu. W tradycyjnym przemyśle kulturowym, zarówno w odniesieniu do praktyk dominacji, jak i oporu, procesy zapośredniczenia (mediacji) zachodziłyby przede wszystkim w porządku reprezentacji. Globalny przemysł kulturowy jest $\mathrm{z}$ kolei procesem medializacji rzeczy

Produkty kulturowe bezpowrotnie utraciły jednakową tożsamość. Przestały wyrażać jednolitą intencję ich wytwórców. Nie nadają wspólnego tonu. Kreują polifoniczność obrazów i znaczeń. Odznaczają się właściwym sobie nieuporządkowaniem, niezdeterminowaniem, automodyfikacją. Rzeczywistość jest pozorowana, jest karykaturą samej siebie. Abstrakcyjne teorie nie wpływają na fakty. Fakty przeszły na stronę fikcji. Fikcyjność tworzy fakty. Pojęcia prawdy i fałszu zostały zawieszone na rzecz napływającego nadmiaru obrazów i informacji. Metamorfoza rzeczywistości w obłędny spektakl, gdzie to, co ważne i nieistotne, zostało upodobnione, wyznaczając społecznemu teatrowi mimetyczną grę pozorów.

We wszystkich swych poszczególnych formacjach - informacji lub propagandzie, reklamie lub bezpośredniej konsumpcji rozrywek - spektakl wyznacza dominujący model życia społecznego. Jest wszechobecną afirmacją wyboru dokonanego już w produkcji, a zarazem konsumpcją jej wytworów. Zarówno forma, jak i treść spektaklu służą

${ }^{4}$ M. Horkheimer, Th. W. Adorno, Dialektyka oświecenia. Fragmenty filozoficzne, przeł. M. Łukasiewicz, Wyd. Krytyki Politycznej, Warszawa 2010, s. 127-128.

5 S. Lash, C. Lury, Globalny przemyst kulturowy. Medializacja rzeczy, przeł. J. Majmurek, R. Mitoraj, Wyd. UJ, Kraków 2011, s. 14-15. 
uprawomocnieniu założeń oraz celów panującego systemu. Spektakl jest również ustawiczną obecnością tego uprawomocnienia, jako że wypełnia większość czasu spędzanego poza sferą produkcji. [...] Społeczna praktyka, którą spowija autonomiczny spektakl, jest również realną całością zawierającą spektakl ${ }^{6}$.

Fikcja, stając się rzecznikiem faktów, ustanawia nową rzeczywistość, w której zagubieni pod lawiną obrazów, gotowi jesteśmy zawierzyć obserwowanym pozorom. Dawna nienaruszalność wiedzy wystawiona jest na próbę metanarracji, uzależniających społeczne praktyki od przejmowanych wzorców.

Życie społeczne powiela gesty i zachowania od ciśn ię te przez wzorce narracyjne; odtwarza ono i gromadzi nieustannie „kopie” opowieści. Nasze społeczeństwo stało się społeczeństwem recy to wa n y m (une société récitée) w potrójnym sensie tego słowa: jest określane jednocześnie przez o p o w i é c i (fabuły reklamowe i informacyjne), przez ich cytowanie oraz nieustanne recy tow a nie.

Opowieści owe mają podwójną i niezwykłą moc przekształcania widzenia w wiarę oraz wytwarzania rzeczywistości za pomocą pozorów. Jest to podwójny przewrót. $Z$ jednej strony nowoczesność, zrodzona niegdyś z chęci obserwacji, która zwalczała łatwowierność i zasadzała się na pakcie pomiędzy widzeniem a rzeczywistością, odtąd przekształcała ową relację i poddaje o gląd o w i to, w co należy w i e r z y ć. Fikcja określa pole, status i przedmioty widzenia ${ }^{7}$.

Kultura popularna wypowiada bowiem nieustające "J'accuse!" zastanemu światu (czy też porządkowi) niezmiennych, utrwalonych matryc pojęciowych. Popkultura jest swoistą modą kulturowa, eksterioryzującą się w witalizmie kulturowym, kulturowym zdynamizowaniu, badającym i bezwstydnie przekraczającym bariery tradycji. O żywotności mody kulturowej decyduje prowadzenie permanentnej komunikacji i walki między swymi wsobnymi aspektami.

Funkcjonowanie kultury to wytwarzanie bądź to wiedzy specjalistycznej, bądź to wiedzy spontanicznej, lecz nie wyłącznie w celu tłumienia jej, tylko w celu wynajdywania powiązań, okazji, nowej wiedzy specjalistycznej, w ruchu mniej lub bardziej uporządkowanym, w którym nieporozumienie często staje się powodem dokonania przypadkowego od-

6 G. Debord, Społeczeństwo spektaklu oraz Rozważania o społeczeństwie spektaklu, przeł. M. Kwaterko, PIW, Warszawa 2006, s. 34-35.

7 M. de Certeau, Wynaleźć codzienność. Sztuki działania, przeł. K. Thiel-Jańczuk, Wyd. UJ, Kraków 2008, s. 187-188. 
krycia. Jednego w każdym razie można być pewnym: kultura, która nie wywołuje mód, jest kulturą statyczną ${ }^{8}$.

O tak pojmowanej kulturze należy myśleć jak o polu wymiany znaków, gdzie każdy spełnia się przez zdobywanie i tracenie znaczeń. Obszar przemieszczania się znaków kulturowych wyjawia sens ich cyrkulacji. Mogą zostać dowolnie wykorzystane i przerobione na inne, zaskakujące znaczenia. Energia popkultury jest nieograniczona, umotywowana zmiennością wzorców, efemeryczną sensownością. Znaczenia wchodzą w stosunki i dyskutują wyłącznie z sobą. Znaki nieustannie ewoluują: same siebie produkuja, nakładają na siebie, negując szansę ustanowienia absolutnego punktu odniesienia, mogącego posłużyć im za oparcie. Kultura w tej perspektywie nie podlega żadnej kontroli.

Cała w ruchu, płynna i rozpływająca się, porządkująca może, ale sama nie uporządkowana, drwiąca sobie bluźnierczo z różnicy między tym, co istotne a co marginalne, co konieczne a co przypadkowe - różnicy tak świętej wszak i nietykalnej dla ładotwórczej intencji. Mniej od poprzedniej [tradycyjnej - M. S.] wizji zachęcająca, bo nie dająca nadziei na portret ostateczny, skończenie miarodajny, autorytatywny ${ }^{9}$.

Popkulturowość odcina się od Fordowskiego rozumienia kultury (piętnowanego przez frankfurtczyków) jako odtwarzania i konsumowania tego samego, przechodząc w niefordowski (postfordowski) model intensywnej kreatywności, osadzonej w różnicy. Przemysł kulturowy reprezentował dyktat towarów, popkulturowość zaś rozwija się w hiperrzeczywistości, w której znaki tracą pierwotnie ustalone walory poznawcze, otwierając się na zupełnie nowe znaczenia; niszcząc dotychczasowe zamknięte systemy.

Rozpleniony znak nie ma już jednak nic wspólnego ze znakiem przymusowym o ograniczonej dostępności, jest jego imitacja jednak nie w skutek wynaturzenia jakiegoś „oryginału”, lecz dzięki poszerzeniu materiału, którego przejrzystość wynikała z nałożonych nań ograniczeń. Nowoczesny znak, który już nie rozróżnia i nie dyskryminuje (jedynie konkuruje z innymi znakami), uwalnia się od wszelkiego przymusu i zobowiązań, staje się powszechnie dostępny, nadal jednak symuluje konieczność, udając, że jest powiązany ze światem ${ }^{10}$.

8 U. Eco, Semiologia życia codziennego, przeł. J. Ugniewska, P. Salwa, Czytelnik, Warszawa 1999, s. 207.

9 Z. Bauman, Ponowoczesność jako źródło cierpień, Sic!, Warszawa 2000, s. 190. 2007.

J. Baudrillard, Wymiana symboliczna i śmierć, przeł. S. Królak, Sic!, Warszawa 
Esencja popkultury polega na rozsadzeniu monocentryzmu sprowadzającego się do polisemii znaczeń. Rozsianie znaczeń powoduje, że każdy znak może być zarówno wzorcem, jak i kopią (zresztą taka dystynkcja przestaje odgrywać najmniejszą rolę).

Wszyscy są tu aktorami i autorami naraz. Żaden z czynów nie jest po prostu naśladownictwem, kopia, graniem z góry napisanej, i to we wszystkich szczegółach, roli (by użyć Derridiańskiej terminologii, każdy czyn jest i t e r a cją, nie r e-iteracją). W każdym czynie wzory odtwarzają się w sposób samoistny i do końca niepowtarzalny; każdy czyn jest „permutacją", szczególnym wydaniem wzoru - nie można być aktorem, nie będąc zarazem autorem... „Wzory" nie istnieją więc inaczej niż w procesie nieustannego i nieustępliwego przekształcania się - ale przekształcenia są rozproszone, wyłaniają się (w miejscach z góry nieprzewidywalnych „kłączowato", jak powiedzieliby Deleuze i Guattari) z drobnych, trudnych nieraz do zauważenia innowacji nieuniknionych w każdym akcie odtwarzania. Nie ma w praktyce, w odróżnieniu od teorii, przedziału między „statyką" a "dynamiką", ciągłością a zmianąa ${ }^{11}$.

Sylwiczna metaforyka Deleuze'jańskiego kłącza ${ }^{12}$, gdzie wszelki punkt zawiera w sobie wszystkie pozostałe (kierując się anty-Leibnizjańską logiką otwartych, upłynnionych monad, przelewających się jedna w drugą), świetnie oddaje charakter rozkrzewiania znaczeń, tworzenia kopii kopii, śmierci oryginału. Krótkotrwała żywotność znaków, z racji zmienności ich odczytów, to opowieść o triumfie kultury popularnej, urzeczywistniającej się i reprezentowanej przez świat kopii, machinę iluzji.

Możemy powiedzieć, że reprezentacja należy do świata indywidualności, więc również do indywidualnej nieśmiertelności. W naszym świecie jest ona ograniczona do wymiaru dobrobytu, luksusu, wyróżnienia. Poza tym wymiarem jest tylko masowo produkowana nieśmiertelność, nieśmiertelność dla mas; szeroko dostępna masowa kopia, pastisz „prawdziwej rzeczy", cechujący się powierzchownym podobieństwem do oryginału z metalu szlachetnego. Możemy powiedzieć, że powtórzenie jest reprezentacją biedaków; odpowiednio, zanikanie, które umożliwia powtórzenie, jest nieśmiertelnością dla biedaków. Ale teraz, przynajmniej, każdy biedak może śnić o uczestnictwie w nieśmiertelności (lub w jej handlowej wersji), ponieważ nieśmiertelność, w jej masowej wersji, oznacza niekończące się powtórzenie ${ }^{13}$.

11 Z. Bauman, Ponowoczesność jako źródło cierpień, s. 193.

12 G. Deleuze, F. Guattari, Kłacze, przeł. B. Banasiak, "Colloquia Communia” 1988, nr 1-3, s. 221-273.

13 Z. Bauman, Śmierć i nieśmiertelność. O wielości strategii życia, przeł. N. Leśniewski, PWN, Warszawa 1998, s. 211. 
Popkultura obraca się w świecie pozorów, chaosmosie swobodnych, wzajemnie przenikających się zjawisko, migotliwej kampowości, krzykliwie mamiącej, nęcącej swobodą wyrazu. Sprowadza się do swoistej metafizyki materii, w której niepodzielnie włada różnica.

Dziś jesteśmy być może bardziej metafizyczni niż dialektyczni. Dialektyka zakłada różnicę ontologiczną: między duchem a materia, bytem a bytami, bazą i nadbudowa, tym samym a innym, przyjacielem i wrogiem. Metafizyka jest tak naprawdę monistycznym systemem immanencji ducha-materii, bazy i nadbudowy. Różnica ontologiczna metafizyki została dziś zastąpiona metafizyką ontologii różnicy. W tej ontologii różnicy każda prosta substancja sama w sobie staje się różnicą. Ta prosta substancja obrazu-materii i różnicy jest podstawową materią globalnego przemysłu kulturowego. Światopoglądem, episteme globalnego przemysłu kulturowego nie jest już dialektyczny, ale metafizyczny materializm, oparty na materialności monady, na rzeczywistości umysłu (tak jak w Matriksie), na koncepcji materii jako wielości, jako różnicy, nie jako tożsamości ${ }^{14}$.

Różnica jest więc noumenalna - leży u podłoża zjawisk, warunkując je, bez możliwości wskazania początku. Pod powierzchnią przedmiotowych obrazów znajduje się - ciągnący się w nieskończoność - wirtualny świat tychże. Tworzy to - jak u Deleuze'a - transcendentalność rachunku różniczkowego, gdzie wszystko we wszystkim jest pasmem różnicujących się ciągów.

Rzecz nie może więc być czymś tożsamym, lecz musi zostać pokawałkowana w różnicy, gdzie znika tożsamość zarówno postrzeganego przedmiotu, jak i postrzegającego podmiotu. Różnica musi się stać żywiołem, ostateczną jednością, musi zatem odsyłać do innych różnic, które nigdy nie przydają jej tożsamości, lecz zawsze różnicują. Każdy składnik serii, będący już różnica, musi wejść w zmienny stosunek z innymi składnikami i w ten sposób ukonstytuować inne serie, pozbawione centrum i konwergencji. W samej serii afirmować trzeba dywergencję i decentrowanie. Każda rzecz, każdy byt musi ujrzeć, jak jego własna tożsamość pogrąża się w różnicy, każdy byt będzie już tylko różnica pośród różnic. [...] A przecież nic nie ginie, skoro każda seria istnieje tylko dzięki powrotowi innych serii. Wszystko stało się pozorem. Przez pozór nie powinniśmy bowiem rozumieć zwykłego naśladownictwa, ale raczej akt, wskutek którego sama idea modelu czy uprzywilejowanej pozycji zostaje zanegowana, odrzucona. Pozór jest instancją zawierającą różnicę samą w sobie jako (przynajmniej) dwie dywergentne serie, którymi gra, znosząc wszelkie podobieństwo, tak że nie można odtąd wskazywać na istnienie oryginału i kopii. $\mathrm{W}$ tym właśnie kierunku należy podążać w poszuki-

${ }^{14}$ S. Lash, C. Lury, Globalny przemyst kulturowy, s. 29. 
waniu warunków już nie możliwego, lecz rzeczywistego doświadczenia (selekcja, powtórzenie itd.) ${ }^{15}$.

Wszystko powraca stale jako odmienne. Immanentna zasada, określająca wszystkie obiekty, kryje się w ich niepodobieństwie. Przedmioty są niczym maski, a seria masek skrywa jedynie inne maski, za którymi nic się nie znajduje. Złudzenie demaskacji czegokolwiek i kogokolwiek wikła obserwatorów w nierozróżnialność realnego i wirtualnego. Oto zwycięski gest różnicy!

Niemniej, kultury popularnej nie należy sprowadzać wyłącznie do medialnej powłoki pozbawionej głębi, gry symulakrów, powierzchownych i ulotnych obrazów, zwyczajnej ornamentyki z odsuniętym na bok znaczeniem. Popkultura nie jest zastygłym pastiszem, lecz organizmem inwencyjnym i zdynamizowanym. Jest fraktalna, prosta, złożona i zmienna. Komunikuje się, emitując niedookreślone produkty, które można dowolnie przekształcać. Zalew produktów (zarówno materialnych, jak wirtualnych) daje szansę przyjęcia obcej identyfikacji, jak i narzucenia jej innym. Ambiwalentny charakter kultury popularnej dopuszcza paradoksy. Margines wolności konsumenckiej może być sprowadzony do utowarowienia samych kupujących.

„Podmiotowość" w społeczeństwie konsumentów, podobnie jak „,towar" w społeczeństwie producentów, jest (żeby sięgnąć po celne pojęcie ukute przez Brunona Latoura) faitishe - całkowicie ludzkim produktem podniesionym do rangi nadludzkiego autorytetu, poprzez puszczenie w niepamięć lub uczynienie nieistotnym jego ludzkiego, nazbyt ludzkiego pochodzenia, wraz z całym ciągiem ludzkich działań, które doprowadziły do jego powstania i były warunkiem sine qua non jego pojawienia się. $\mathrm{W}$ przypadku towarów $\mathrm{w}$ społeczeństwie producentów był to akt kupna-sprzedaży zdolności do pracy producentów, który, poprzez obdarzenie jej wartością rynkowa przekształcał owoc pracy w towar - w sposób niewidoczny (ponieważ ukryty) w autonomicznej interakcji towarów. W przypadku podmiotowości w społeczeństwie konsumentów przychodzi kolej na kupno i sprzedaż symboli wykorzystanych do konstrukcji tożsamości - tego rzekomo publicznego wyrazu własnego ,ja” $[\ldots]^{16}$.

Konsument jest istotą zachłanną na okazję nabycia zupełnie nowej tożsamości $\mathrm{w}$ atrakcyjnej cenie. Liczy się $\mathrm{w}$ tej niepohamowanej rozpuście konsumpcyjnej kompulsywne nabywanie coraz to nowych wrażeń, a nie rzeczy.

15 G. Deleuze, Różnica i powtórzenie, przeł. B. Banasiak, K. Matuszewski, Wydawnictwo KR, Warszawa 1997, s. 100, 116.

16 Z. Bauman, Konsumowanie życia, przeł. M. Wyrwas-Wiśniewska, Wyd. UJ, Kraków 2009, s. 20-21. 
Gra, w której bierze udział konsument, to nie żądza kupowania i posiadania, nie gromadzenie dóbr $\mathrm{w}$ materialnym, namacalnym sensie tego słowa; tutaj chodzi o wzbudzenie nowych, nieznanych dotąd wrażeń. Konsumenci są przede wszystkim zbieraczami w r a ż én; kolekcjonują r z e c z y jedynie wtórne, jako pochodne doznann ${ }^{17}$.

Konsumpcja stała się nieodłącznym rytem dnia powszedniego, przyjmując autoteliczną formułę i tracąc względy utylitarne.

Nie potrzebowałaby [konsumpcja] żadnych innych uzasadnień poza samym aktem konsumowania, nie mówiąc już o dowodach na jej użyteczność w podtrzymywaniu przydatności robotnika do pracy. Konsumpcja powinna stać się „,absolutnym celem dla siebie” i „powołaniem” („powołanie" ma przecież charakter kompulsywnego i nieodpartego, uzależniającego i samonapędzającego się popędu, który ani nie potrzebuje, ani nie dopuszcza racjonalnego wyjaśnienia). Ma to być zarazem jedynie powołanie, powołanie wykluczające rywalizację, wszechobejmujące i samopodtrzymujące się. Takie, w odniesieniu do którego ocenia się i wyjaśnia to, co przyzwoite i nieprzyzwoite, triumfy i porażki, sukcesy i niepowodzenia, życiowe dole i niedole ${ }^{18}$.

Jednakże popkultura wyzwala w ludziach pokłady kreatywności do przeciwstawiania się jej bezwzględnej sile. Poietyczność popkultury przeciwstawia się monokulturowości. Konsument ma wolną rękę może być biernym odbiorcą albo czynnym producentem.

Zatem idzie o model produkcji, który zdoła: po pierwsze - wskazać drogę innym wytwórcom, po drugie - przekazać im usprawniony aparat. A aparat ten jest tym lepszy, im więcej konsumentów pozyska dla produkcji; krótko mówiąc - gdy z czytelników lub widzów potrafi zrobić współpracowników ${ }^{19}$.

Można więc nazywać kulturę popularną wielkim rezerwuarem znaczeń, których wybór (dopasowanie) jest uzasadniony sytuacja, nastrojem bądź ideologią.

Noszenie podartych dżinsów jest przykładem sprzeczności typowych dla kultury popularnej: sprzeciw wobec danego zjawiska musi koniecznie być wyrażany za jego pomocą. Sprzeczność cechuje kulturę popularną w społeczeństwach, w których władza rozkłada się nierównomiernie

17 Idem, Globalizacja. I co z tego dla ludzi wynika, przeł. E. Klekot, PIW, Warszawa 2000, s. 99.

18 Idem, Społeczeństwo w stanie oblężenia, przeł. J. Margański, Sic!, Warszawa 2006, s. 174 .

19 W. Benjamin, Anioł historii. Eseje, szkice, fragmenty, przeł. K. Krzemieniowa i in., Wydawnictwo Poznańskie, Poznań 1996, s. 177. 
według kategorii klasowych, genderowych, rasowych i innych, pozwalających na wytłumaczenie różnic społecznych. Kultura popularna jest kulturą ludzi podporządkowanych i pozbawionych władzy, w związku z czym wpisane są w nią zawsze znaczenia odnoszące się do stosunków władzy, ślady sił dominacji i podporządkowania, które znajdują się w centrum naszego systemu społecznego, a zatem i naszego społecznego doświadczenia. Jednocześnie kultura popularna wykazuje oznaki uchylania się od owych sił lub oporu wobec nich, a więc zaprzecza samej so$\mathrm{bie}^{20}$.

Znaczy to jednoznacznie, że kultura popularna może w swym łonie działać kontrkulturowo. Wypowiadanie posłuszeństwa władzy wprowadza jawne sprzeciwienie się dyktatowi mody czy bunt wobec światopoglądu przenikającego elementy kultury popularnej. Jednakże produkt masowy z łatwością adaptuje się do nowych potrzeb rynkowych. Gest zwycięstwa masowości dostrzegalny jest również w wytworach subkulturowych, oficjalnie kontestujących kulturę ogółu, lecz na niej bazujących.

Ekskorporacja to proces, w którym grupy podporządkowane tworzą własną kulturę na podstawie zasobów i towarów dostarczanych im przez system rządzący. Jest ona kluczowym zjawiskiem w kulturze popularnej, ponieważ $\mathrm{w}$ społeczeństwie uprzemysłowionym jedynymi środkami, z których ludzie mogą wytwarzać własne subkultury, są środki dane im przez system, który sobie owe grupy podporządkował. Nie istnieje żadna „autentyczna” kultura ludowa, która mogłaby być propozycją alternatywną i dlatego kultura popularna musi polegać na sztuce radzenia sobie za pomocą dostępnych środków ${ }^{21}$.

Świat konsumpcji pochłania walka o zysk. Producenci starają się za wszelką cenę wypromować dany produkt, wykorzystując coraz bardziej śmiałą i przekraczającą kolejne bariery ikon współczesności - reklam. Tocząca się bitwa dotyczy środków dostępnych i sposobów ich wykorzystania. Zwycięstwo odnosi ten, kto lepiej zaprezentuje je w nowym świetle. Proces opozycji wewnątrzkulturowych, implikujących ciągłą polaryzację i napędzających efektów zmian jest paralelny do słynnej dialektyki pana i niewolnika, spotykanej u Hegla.

Panem jest świadomość istniejąca d la s i e b i e, ale już nie samo tylko jej pojęcie, lecz istniejąca dla siebie świadomość, która zapośredniczona jest ze sobą samą przez i n n ą świadomość, mianowicie taka, do której istoty należy to, że jest połączona z samoistnym by te m, czyli z elementem rzeczowym w ogóle. Pan odnosi się do obu tych momentów: do r z e c z y

20 J. Fiske, Zrozumieć kulturę popularna, s. 5.

21 Ibidem, s. 18. 
jako takiej, do przedmiotu pożądania, i do świadomości, dla której tym, co istotne, jest element rzeczowy; a skoro pan a) jako pojęcie samowiedzy jest bezpośrednim odnoszeniem się bytu dla siebie, ale b) teraz istnieje zarazem jako zapośredniczenie, czyli jako byt dla siebie, który jest tym bytem dla siebie tylko dzięki „innemu”, więc odnosi się on a) bezpośrednio do obu [tych momentów] i b) pośrednio do każdego z nich poprzez drugi. Pan odnosi się do poddanego w sposób pośredni poprzez samoistny byt; poddanyjest bowiem przykuty właśnie do tego samoistnego bytu; są to jego kajdany, od których nie potrafił abstrahować w walce i dlatego okazał się [kimś] niesamoistnym, mającym swą samoistność w elemencie rzeczowym. Pan jest zaś władzą nad tym bytem, ponieważ w walce wykazał, że jest to dla niego coś tylko negatywnego; a skoro pan panuje nad samoistnym bytem, zaś ów byt panuje nad drugim, więc za sprawą tego sylogizmu drugi jest mu podporządkowany. Podobnie też odnosi się pan w s p o s ób pośredni - poprzez poddanego - do rzeczy. Poddany, jako samowiedza w ogóle, odnosi się do rzeczy również negatywnie i ją znosi, ale jest ona dla niego zarazem samoistna i dlatego nie może przez swoje negowanie uporać się z nią w sposób definitywny, unicestwiając ją czyli jedynie tę obrabia. Dla pana natomiast dzięki temu pośrednictwu staje się możliwe bezpośrednie odnoszenie się [do rzeczy] jako czyste jej ne gowanie, czyli spoży wa nie. Udaje mu się to, co nie udało się pożądaniu: uporanie się z rzeczą i zaspokojenie siebie poprzez [jej] spożywanie. Pożądaniu nie udało się to ze względu na samoistność rzeczy; pan zaś, wsunąwszy między siebie a rzecz poddanego, wiąże się dzięki temu tylko z niesamoistnością rzeczy i spożywa ją w sposób czysty; natomiast aspekt samoistności [rzeczy] pozostawia poddanemu, który ją obrabia ${ }^{22}$.

Kultura popularna zawsze pozostawia w sobie margines swobody, wyprowadzający kontrkulturowe reakcje. Społeczeństwo nie musi stawać się jednorodną masą. Często opór jest wskazany, a nawet konieczny, gdy „nadprodukcja” symboli staje się jednoznaczna, nie dopuszczająca innych do ekspresji odmienności.

Tekst, który ma wejść do kultury popularnej, musi zatem uosabiać zarówno siły zapewniające dominację, jak i okazje do występowania przeciwko niej. W takich okolicznościach stawianie oporu tym siłom czy też unika-

${ }_{22}$ G. W. F. Hegel, Fenomenologia ducha, przeł. Ś. F. Nowicki, Aletheia, Warszawa 2002, s. 137. W podobnym tonie wypowiada się sam John Fiske: „Kultura popularna zawsze funkcjonuje w obrębie stosunków władzy; nigdy nie traci oznak bezustannej walki między dominacją a podporządkowaniem, między władzą a różnymi formami oporu wobec niej lub jej unikania, między strategią wojskową a taktyką partyzancką. Ocena równowagi sił w tej walce nigdy nie jest prosta. Czy istnieje osoba, która mogłaby stwierdzić, kto wygrywa wojnę partyzancką w którejkolwiek jej fazie? Istota zarówno partyzantki, jak i kultury popularnej polega na tym, że żadnej z nich nie da się pokonać". J. Fiske, Zrozumieć kulturę popularna, s. 20. 
nie ich odbywa się z pozycji osoby podporządkowanej, a nie całkowicie ubezwłasnowolnionej. Ludzie tworzą kulturę popularną na styku dwóch płaszczyzn: tej powstałej wokół produktów przemysłów kultury oraz tej wynikającej z codzienności. To społeczeństwo odpowiada za jej narodziny: kultura popularna tworzy się w środku, oddolnie; nie da się jej narzucić odgórnie. [...] To, że dostarcza on [system] wyłącznie towarów, kulturowych czy materialnych, nie oznacza, że proces ich konsumpcji można jednoznacznie zaszufladkować pod hasłem utowarowienia ludzi, tj. zmieniania ich w jednorodną masę zdaną na łaskę wielkich baronów przemysłu ${ }^{23}$.

Mit zachodniej władzy wiąże się ze strategiami władzy, których polem eksperymentalnym (i weryfikowalnym) jest kapitalizm. Kulturę popularną można więc postrzegać jako chroniczny rytualizm, którego fetyszem staje się towar (a intensywność kultu jest współzależna z jego brakiem lub dostępnością). Wobec tego kulturę mas można ujmować zarówno przez autentyczność, jak i nieautentyczność - obydwa pojęcia są w świetle tej interpretacji jak najbardziej zgodne; wzajemnie się uzupełniają. Autentyczność to sfera władzy, dla której czynnik posiadania może z jednej strony prowadzić do egalitaryzmu wszystkich wobec rynku; z drugiej zaś zradzać niepokonywane dystanse, nierówności, podziały. Natomiast nieautentyczność masowości mieści się w odejściu od czegoś, co nazwałbym rdzeniem oryginalności, na rzecz rozpuszczenia produkcji w miriadach kopii, zawierających pozorny ślad niepowtarzalności. Są marnymi - powiadając za Jeanem Baudrillardem - symulakrami, z których należy wyznaczyć trzy porządki:

- symulakry naturalne, naturalistyczne, oparte na obrazie, naśladownictwie i podrabianiu, harmonijne, optymistyczne oraz zmierzające do przywrócenia, odtworzenia bądź ustanowienia w sposób naturalny natury na wzór Boga;

- symulakry produktywne, produktywistyczne, oparte na energii, sile, zmaterializowane za pomocą maszyny w całym systemie produkcji ich prometejskim celem jest globalizacja i bezustanna ekspansja, uwolnienie nieskończonej energii (pragnienie stanowi część utopii wiążących się z tym porządkiem symulakrów);

- symulakry symulacji, oparte na informacji, modelu, cybernetycznej grze - całkowita operacjonalizacja, hiperrzeczywistość, celem ich jest uzyskanie całkowitej kontroli ${ }^{24}$.

Teoria symulakrów doskonale oddaje dramat ponowoczesności nieoryginalność wszystkich reprezentacji. Zatrata oryginału pozwala

23 J. Fiske, Zrozumieć kulturę popularna, s. 25-26.

24 J. Baudrillard, Symulakry i symulacja, przeł. S. Królak, Sic!, Warszawa 2005, s. 149. 
odnosić znaczenie nie tyle do przedmiotu, co jego kopii. Odtąd mamy do czynienia z konstelacją kopii, swobodnym (niepoddającym się kontroli) polilogiem kopii. Epoka powtórzenia objawia się w zacieraniu podziału między seryjnością a innowacyjnością; między tym, co realne a wirtualne. Przedziwna nadrzeczywistość bytujących symulakrów, kładzie kres rozróżnieniu faktyczności i pozorności. Symulakrum jest jednocześnie tym, co dane, i realnością spreparowaną (rzeczywistością wyzbytą rzeczywistości). Symulakry zatem skupiają w sobie to, co realne i wirtualne. Stanowią taki rodzaj „rzeczywistości”, który nie posiada zewnętrzności, zezwalającej na korespondowanie z innymi obiektami; same dla siebie stanowią zamknięte światy - światy wewnętrzności, w których rzeczywistość i iluzja są tym samym. Symulakra zagrażają rzeczywistości, rozprowadzając w niej swą fałszywość, za prawdziwość przyjmowaną. Symulakry nie są zatem pochodnymi rzeczy, wprost przeciwnie, to one rzeczy wywołują - są bardziej rzeczywiste od samej rzeczywistości, narzucając moc perswazji.

Role się teraz odwracają: to, co narodziło się jako reprezen ta cja rzeczywistości, stało się standardem i miarą dla rzeczywistości, jaką rzekomo nadal reprezentuje. Mało która rzeczywistość potrafi tym standardom sprostać - a więc tym gorzej dla niej. „Rzeczywistość” (cokolwiek to słowo mogłoby w nowych warunkach znaczyć) usuwa się na plan dalszy, chowa w cieniu przedstawień o sobie, traci samoistne kontury, wtapia we własną reprezentację. [...] Nie jest już jasne, co jest rzeczywistościa, a co jej obrazem; co jest „naprawdę", a co „na niby" ${ }^{25}$.

Podejście krytyczne do kultury popularnej winno podtykać jej zwierciadło, w którym wszyscy mogą i powinni przeglądać się do woli. Mogłoby to zaradzić siłom opanowującym świadomość masową, a tym samym ograniczyć (czy to jest wykonalne, to już inne pytanie) żywioł odtwórczej kreatywności, pochłaniający i upowszechniający surogat wszystkiego (od świata wartości i ideologii, po narzędzia użytku codziennego). Optymistyczne prognozy głosza, że można tylko bezpiecznie redukować (tj. zapobiegać radykalizacji) nieogarnionemu potencjałowi popkultury. Pesymiści zaś uznają kulturę masową za oczywisty projekt albo projekt idealny naszych nieprzewidywalnych czasów. Stąd ciągłe zmaganie z utopią dobrobytu.

Społeczeństwo konsumpcyjne nie wytwarza własnych mitów dlatego, że samo jest dla siebie własnym mitem. [...] Konsumpcja jest mitem. Oznacza to, że jest ona wy powiedzią współczesnego społeczeństwa o sobie samym, językiem, w jakim mówi

25 Z. Bauman, Dwa szkice o moralności ponowoczesnej, Instytut Kultury, Warszawa 1994, s. 25. 
o sobie samym i jakim się ze sobą porozumiewa. A w pewnym sensie jedyną obiektywną rzeczywistością konsumpcji jest i d e a konsumpcji, refleksyjna i dyskursywna konfiguracja, która powtarzana niestrudzenie zarówno w języku codziennym, jak i dyskursie intelektualnym, nabrała mocy kategorii z d row or o z s ą d k owe j.

Nasze społeczeństwo myśli i mówi o sobie jako o społeczeństwie konsumpcji. O ile cokolwiek konsumuje, to konsumuje samo siebie jako społeczeństwo konsumpcji, jako ideę. Reklama stanowi triumfalny pean na cześć owej idei ${ }^{26}$.

\section{Popular culture as a semiology of everyday life}

\section{Keywords}

Popular culture, sign, difference, dispersion, consumption, creativity, medialisation, modern society

The article presents meaning of popular culture. Category of popularity in culture shows how human's creativity could express obscene, silly and vulgar things. Society actively participles in popular culture, changed famous works of art, music, movies, literature, discovered a new senses and uses. Social practices could too surrender of the media's performance or being on opposition to cultural mainstream. On the other level popular culture means specific material metaphysics, representing of difference. In this vision sign losing signification. Everything belong to anarchy of interpretations. The reality is a endless series copy of copies, without root. All is a imitation, simulation, the game of convention, kitsch and parody. Infinitive, where everyone made up of experts, zealots, spectators and artificers.

26 J. Baudrillard, Społeczeństwo konsumpcyjne. Jego mity i struktury, przeł. S. Królak, Sic!, Warszawa 2006, s. 270-271. 